REVIEW

\title{
HSP70 plays an ambiguous role during viral infections in plants
}

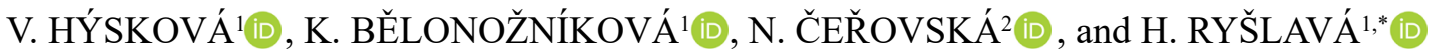 \\ ${ }^{1}$ Department of Biochemistry, Faculty of Science, Charles University, CZ-12843 Prague 2, Czech Republic \\ ${ }^{2}$ Institute of Experimental Botany of the Czech Academy of Sciences, CZ-16500 Prague 6, Czech Republic
}

${ }^{*}$ Corresponding author: E-mail: helena.ryslava@natur.cuni.cz

\begin{abstract}
Heat shock and almost all types of stresses associated with oxidative stress are accompanied by heat shock protein (HSP) expression. HSPs are involved in refolding denatured proteins and directing unrepairable proteins for degradation. Thus, under stress conditions, HSPs help to restore cellular balance. However, in virus-infected plants, HSP70 can have both positive and negative effects because viruses usually recruit HSP70. HSP70 can promote the replication and translation of the viral genome, the formation of viral replication complexes, and the propagation of viral particles from cell to cell and throughout the plant. HSP gene silencing in various virus-host plants systems and the comparison of susceptible and resistant species have shown that HSPs70 accelerate the development of infection. Conversely, during the process known as thermotherapy, the temperature increase inhibits viral replication in some host and virus systems. The success of thermotherapy depends not only on the temperature and treatment period or duration but also on the plant species and viral strain. In this review, we discuss the ambiguous role that HSPs70 play during viral infections in plants towards weighing the balance between their positive and negative functions.
\end{abstract}

Keywords: acquired tolerance, heat shock, host factor, plant viruses, thermotherapy, virus propagation.

\section{Introduction}

Heat shock proteins (HSPs) are a family of mainly stressinduced proteins whose primary function is to refold denatured proteins. HSPs are divided into six groups according to their relative molecular mass and primary structure homology (Wang et al. 2004, Park and Seo 2015). The genes that encode HSPs are found in different cell compartments, and HSP expression is controlled by transcriptional factors known as heat shock factors (HSFs) (Haq et al. 2019).

In particular, HSP70 is arguably the most conserved protein family among all the organisms, from bacteria to plants and animals. The number of members in different
HSP70 families ranges from 18 in Arabidopsis thaliana and 20 in Solanum tuberosum, through 30 in Oryza sativa to 61 in Nicotiana tabacum (Liu et al. 2018, Song et al. 2019). HSP70 are crucial for cells as constitutive and ubiquitously expressed proteins, but HSP70 expression is also induced, not only by heat shock (HS), but by almost all types of plant stresses as well (Park and Seo 2015, Usman et al. 2017).

In the classical model for stress activation of HSPs, the presence of stress-induced unfolded proteins in the cell causes the release of HSPs from their constitutive inhibitory association with HSF monomers, although this model could involve more pathways, especially at temperatures that do not unfold proteins. The unfolded

$\overline{\text { Received }} 2$ October 2020, last revision 14 December 2020, accepted 7 January 2021.

Abbreviations: CP - coat protein; HS - heat shock; HSC70 - heat shock cognate 70; HSF(s) - heat shock factor(s); HSP(s) - heat shock protein(s); RdRp - viral coded RNA-dependent RNA polymerase; ROS - reactive oxygen species; UPR - unfolded protein response; VRC - viral replicase complex.

Acknowledgements: We sincerely apologize to colleagues whose publications could not be cited here owing to space constrains. The authors thank Dr. Carlos V. Melo for English proofreading this review. This work was supported by the Charles University, projects SVV260427/2020 and GA UK No. 1304119 and the Ministry of Education, Youth and Sports of CR from European Regional Development Fund-Project "Centre for Experimental Plant Biology" (grant number CZ.02.1.01/0.0/0.0/16_019/0000738).

Conflict of interest: The authors declare that they have no conflict of interest. 


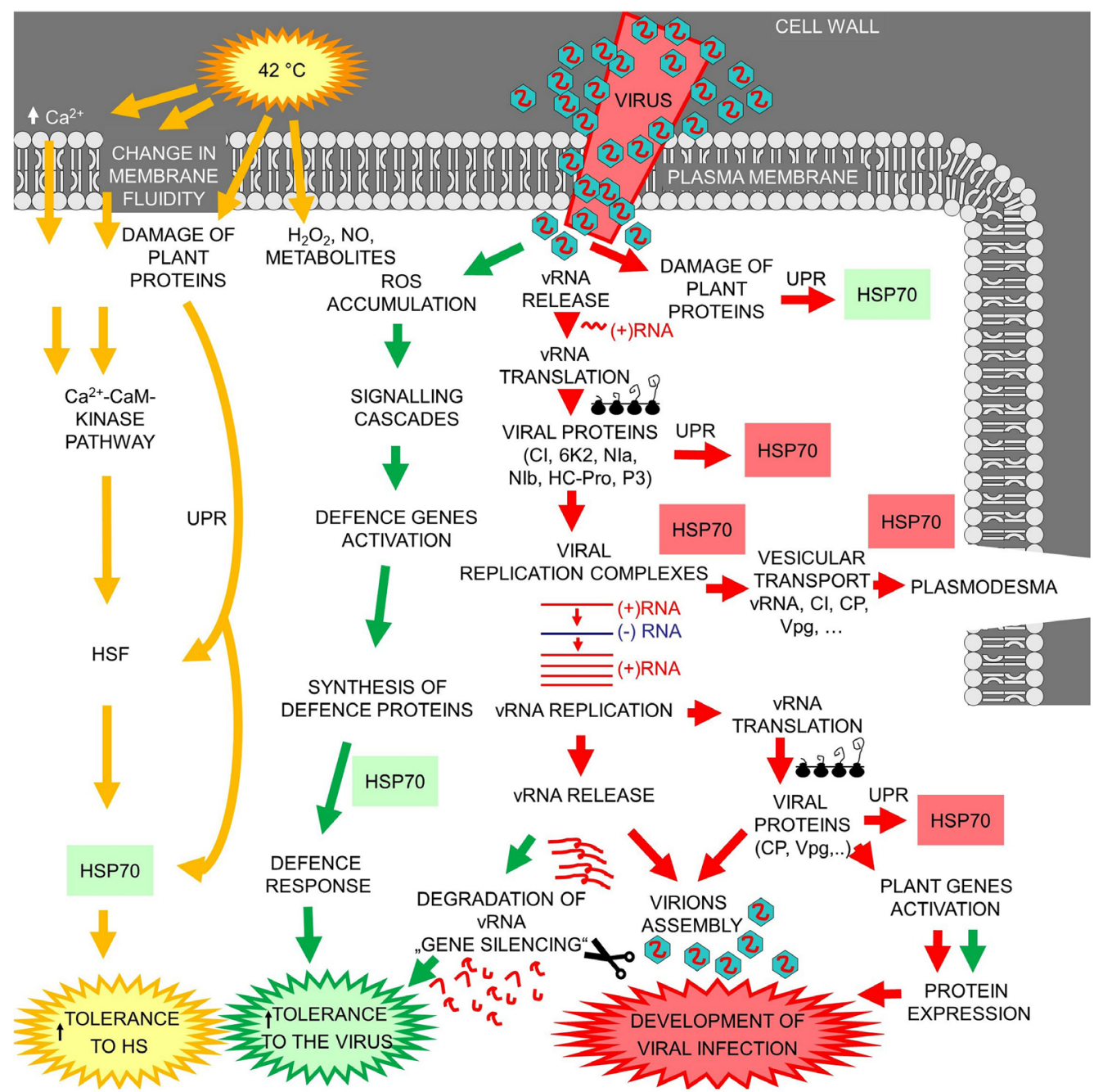

Fig. 1. The main events in the potyviral infection cycle (red) and during HS response (yellow). Heat shock proteins (HSP70) are formed to help plants respond to both stressors (green), but HSP70 can also be misused by viral particles to facilitate their propagation (red). The scheme represents the complexity of HSP70 involvement in the stress situation. Abbreviations: CI - cytoplasmic inclusion, CP - coat protein, HS - heat shock, HSF - heat shock factor, NIa - nuclear inclusion type a with proteolytic activity, NIb - potyviral RNAdependent RNA polymerase, 6K2 - membrane associated protein, UPR - unfolded protein response, VPg - viral genome linked protein. The viral replication scheme was modified from Ivanov et al. 2014.

protein response (UPR) is a signaling pathway activated in cells in response to stresses that impair protein stability. Changes in ambient temperatures are sensed via a complex network of molecular sensors located in different cell compartments: the plasma membrane sensing mechanism, which triggers a specific inward calcium flux, UPR sensors in endoplasmic reticulum and cytosol and histone decreased occupancy in the nuclei. These signals generated by different sensors are integrated by a signal transduction network that involves calcium fluxes, calmodulin, protein kinases, phosphatases, and transcriptional regulators, such as HSFs (Mittler et al. 2012).

In response to heat stress, HSP70 is activated as shown in Fig. 1. Pre-treatment of a plant with a moderately elevated temperature can enhance heat stress tolerance and accelerate recovery after stress (Prerostova et al. 2020). During this process (acquired thermotolerance), plants sense an elevation in ambient temperature and initiate signal transduction networks, which regulate the expression of several genes, including those encoding HSPs and reactive oxygen species (ROS)-scavenging enzymes, to increase their thermotolerance. The integration of hormone and radiation signaling, circadian clock, and high ambient temperature regulates plant thermoresponsive growth (Li et al. 2018). In the absence of heat stress, some HSP family members are nevertheless constitutively expressed, and these family members are known as heat-shock cognate proteins HSC70 (Duck and Folk 1994).

HSPs70 have a highly conserved primary and 3D structure. The protein consists of two domains. The $\mathrm{N}$-terminal domain binds $\mathrm{ATP}, \mathrm{Mg}^{2+}$, and $\mathrm{K}^{+}$ions and has ATPase activity, whereas the $\beta$ strands and loops of the C-terminal domain form the substrate-binding pocket (Frydman 2001, Hartl et al. 2011). The HSP70 substrate binding and release cycle is exclusively regulated by ATP binding and hydrolysis, whereby HSP70 switches between 
(ATP-bound) low- and (ADP-bound) high-affinity states. The former is the open form, which can bind to the substrate protein. Another molecular chaperone, HSP40, is also required for initial protein binding in this cycle (Mayer and Bukau 2005, Doubnerova and Ryslava 2014).

HSPs 70 act as chaperones, stabilizing nascent proteins during protein folding, assembling or disassembling multi-protein complexes, assisting protein unfolding, transporting, and sorting organelle-specific and secretory proteins into subcellular compartments or the extracellular space, respectively (Doubnerova and Ryslava 2014, Asea et al. 2016, Anaraki et al. 2018). HSPs 70 are also involved in preventing protein aggregation, repairing misfolded proteins or targeting irreparable proteins for degradation by the ubiquitin-proteasome system. Furthermore, HSP70 overexpression in plants positively correlates with acquired thermotolerance and results in enhanced tolerance to abiotic stress treatments (Wang et al. 2004, $\mathrm{Su}$ and Li 2008), whereas HSP70 downregulation reduces tolerance to abiotic stresses (Lee and Schoffl 1996, Su and Li 2008). Thus, the HSP70 system plays a key role in plants recovering from various biotic and abiotic stresses (Usman et al. 2017, Anaraki et al. 2018).

To respond to biotic stresses (viruses, bacteria, fungi, and nematodes), plants have evolved different strategies, signal perception, transduction, and activation of the immune system, including stress-related HSPs (Haq et al. 2019). Pathogen-derived homologs of HSP70 may be involved in pathogenesis (e.g., facilitation of colonization) (Ghazaei 2017), but plant HSPs70 expressed in response to stress caused by pathogens with their own HSPs is mostly associated with beneficial effects. For example, HSPs play a key role in defense against virulent bacterial strains, and along with PR proteins, HSPs are more effective against fungal pathogen or work in cooperation with antioxidant-related enzymes to develop resistance against nematodes (for more examples, please refer to the review by Haq et al. 2019). However, the interaction between viral infection and HSP70 is highly complex and ambiguous. Unlike eukaryotes and bacteria, viruses lack HSPs and rely on host HSPs for protein folding (Bolhassani and Agi 2019). It seems that viruses do not encode a specific inducer of HSP70. The initiation of chaperons' response was associated with production of virus-specific proteins and the process could be analogous to the UPR in the endoplasmic reticulum as shown for Turnip mosaic virus and Turnip crinkle virus (Aparicio et al. 2005). The concentration of the insoluble viral coat protein of Tobacco mosaic virus was in correlation with the induction of HSP70 (Jockusch et al. 2001). Nascent viral protein or misfolded cellular proteins compete with HSF for HSP70 binding, which results in an increased amount of free and active HSF (Morimoto et al. 1994, Kim and Oglesbee 2012).

\section{How does temperature affect the course of viral infections?}

Elevated temperatures lead to HSP synthesis. On the one hand, HSP expression can help maintain homeostasis and proteostasis in the plant cell, even under stress conditions. On the other hand, it can help viral nucleic acid replication, protein synthesis and particle assembly, as well as virus spread to other cells (Nagy et al. 2011, Verchot 2012, Jiang et al. 2014, Heinlein 2015). Accordingly, HSP70 silencing or inhibition prevents efficient viral infection. This effect has been shown in plants infected with Rice stripe virus (Jiang et al. 2014), Turnip mosaic virus (Dufresne et al. 2008, Jungkunz et al. 2011), Tomato yellow leaf curl virus (Gorovits and Czosnek 2017), Red clover necrotic mosaic virus (Mine et al. 2012), Tomato bushy stunt tombusvirus (Wang et al. 2009a), Abutilon mosaic virus (Krenz et al. 2010), Pepino mosaic virus (Mathioudakis et al. 2012), and Potato virus A, $X$, and $Y$ (Hofius et al. 2007, Chen et al. 2008, Hafren et al. 2010). However, elevated temperatures may aid in defensive reactions against viruses, as demonstrated in thermotherapy experiments. Thermotherapy usually involves subjecting plants to a slightly elevated temperature for a long time until HSP synthesis stops increasing and is hindered by other mechanisms. The success of thermotherapy depends not only on the temperature and treatment period or duration but also on the plant species and virus strain (Tan et al. 2010, Kwon et al. 2012, Achachi et al. 2014).

The balance between the success of a virus and that of a plant depends on the plant species, its health and developmental stage, on the virus species and strain, and on abiotic factors, including temperature. In this context, the role of HSP70 may vary from supportive to deleterious, depending on the nature of the infectious agent and possibly on the host itself (Asea et al. 2016).

\section{When the elevated temperature helps the plant}

In general, HSP70 synthesis under abiotic stress conditions is associated with positive effects on plants (Haq et al. 2019). Many factors affect the ability of a virus to multiply and penetrate plants and their ability to activate defense reactions and to prevent virus propagation. In addition to their antiviral innate immunity based on pathogenassociated molecular pattern (PAMP)-triggered immunity (PTI) and effector-triggered immunity (ETI), plants degrade viral nucleic acids via gene silencing. However, viral pathogens continuously develop new strategies to overcome host defenses (Gouveia et al. 2017, Carr et al. 2019, Gaffar and Koch 2019).

HSPs90 regulate stomatal development under acute heat stress in Arabidopsis. Acute stress suppresses stomatal development in a HSP90-dependent manner (Samakovli et al. 2020). Temperature strongly affects plant-virus interactions. The increase in temperature boost the defense response (RNA silencing) in Nicotiana benthamiana plants infected with Tobacco ringspot virus. In contrast, in the cold, the amount of central molecules 
of RNA silencing (siRNAs) rapidly decreases, and plants become more susceptible to viruses (Szittya et al. 2003).

A number of recent studies have provided evidence for connections between HSFs, HSPs, ROS, and ROS scavengers upon heat stress. In a recently proposed model, HS induced a short-term positive and a long-term negative feedback loop in the HSF signaling pathway (Driedonks et al. 2015). Overexpression of small HSPs in Arabidopsis and tobacco enhanced the activity of antioxidant enzymes (Jiang et al. 2009, Sun et al. 2012). Accordingly, HSPs may decrease the concentration of ROS by protecting the conformation of ROS scavenging proteins. This model for interactions between HSFs, HSPs, ROS, and ROS scavengers also seems applicable to stresses other than heat and may explain the phenomenon of crossacclimation (Driedonks et al. 2015). Plants likely show defense signaling crosstalk and take advantage of HSP70 acquired by abiotic stress for protection against biotic stress. However, the mechanism of this process remains unknown, and the response to prolonged exposure to elevated temperatures likely differs from acute exposure to HS. Heat treatment may not eliminate viruses at all, but it reduces virus multiplication and translocation in plants, and virus elimination requires long treatment periods (Kwon et al. 2012).

\section{Thermotherapy}

Outbreaks of virus disease are often associated with low temperature, whereas high temperature is frequently associated with attenuated symptoms ("heat masking") and with low virus content in virus-infected plants (Szittya et al. 2003). Thermotherapy is the most common method for virus eradication because virus content can be reduced when plants are heat-treated. Thermotherapy temperature and time application depend on the virus present and plant cultivar sensitivity to heat (Aguilar-Camacho et al. 2016). In general, the higher the temperature and the longer the exposure are, the higher the virus eradication will be. Often, thermotherapy $35-42{ }^{\circ} \mathrm{C}$ for $4-6$ weeks is applied to the target plants, albeit depending on the specific virus-plant system (Wang et al. 2018). Some examples of effective thermotherapy schemes for virus eradication are outlined in Table 1. Thermotherapy using alternating day/night temperatures was found to alleviate the negative effects of a high constant temperature (Lizárraga et al. 2017, Wang et al. 2018). Thermotherapy could be applied as both hot-air and hot-water $\left(37^{\circ} \mathrm{C}\right)$ treatments, which are suitable for example for eliminating Potato leaf roll virus from potato tubers (Abbas et al. 2016). Recently, the effect of thermotherapy has been amplified by combining cryotherapy with chemotherapy (Mathew et al. 2021). Salicylic acid- and $\mathrm{H}_{2} \mathrm{O}_{2}$-induced thermotolerance and their long-time effects significantly increased postthermotherapy survival in Potato virus $X$-infected microplants (Aguilar-Camacho et al. 2016). Therefore, studies on oxidative stress physiology and on the fate of HSPs during thermotherapy could elucidate the balance between the positive and negative functions of HSPs in viral propagation.

\section{When the elevated temperature helps the virus}

In addition to positive effects, HSP70 expression can have negative effects on virus-infected plants because viruses usually recruit HSP70. The possible involvement of HSP70 in viral infection is shown in Fig. 1. Generally, during viral infections, many viral proteins are folded by plant HSP molecular chaperones (Milani et al. 2016). HSP70, HSC70, the J-domain chaperons, and HSP90 were associated with some plant viruses (Table 2). As shown in Table 2, HSPs70 are an infection factor for many plant viruses.

The replication and translation of the viral genome, the formation of viral replication complexes, and the propagation of viral particles from cell to cell and throughout the plant can all be promoted by HSP70 (Mayer and Bukau 2005, Hafren et al. 2010, Nagy et al. 2011, Jiang et al. 2014, Lohmus et al. 2017, Yang et al. 2017). The identification of host factors recruited to the replicase complex helps to elucidate virus-cell interactions and to reveal mechanistic components required for viral nucleic acid replication (Dufresne et al. 2008). The viral-coded RNA-dependent RNA polymerase (RdRp) is responsible for synthesizing viral progeny in infected cells by positive strand RNA viruses (Pogany and Nagy 2015). Host HSP70 are required for RdRp within virusinduced membrane vesicles or replication complexes on intracellular membrane systems (Dufresne et al. 2008, Mine et al. 2012, Pogany and Nagy 2015, Yang et al. 2017). Furthermore, the RdRp of several positive-strand RNA viruses is initially inactive to avoid viral synthesis in cytosol, which would rapidly induce cellular antiviral responses. Pogany and Nagy (2015) identified co-opted cellular HSP70 and neutral phospholipids as activators of Tomato bushy stunt tombusvirus $\mathrm{RdRp}$ in vitro. In addition, these authors found that the membrane-bound tombusvirus replicase complex (VRC) consist of RdRp, the viral p33 RNA chaperone and several co-opted host proteins, one of which is HSP70. HSP70 and HSP90 were identified as host factors required for Red clover necrotic mosaic virus RNA replication. These chaperones promote VRC assembly by binding to $\mathrm{p} 27$, a virus-encoded component of the replicase complex (Mine et al. 2012). Furthermore, the furoviral replicase of the Chinese wheat mosaic virus recruits both Triticum aestivum L. HSP70 and Nicotiana benthamiana HSP70 from the cytoplasm or nucleus to the inclusion-like structures, suggesting that both HSPs70 may be recruited into VRC and promote furoviral infection (Yang et al. 2017). In addition, Yang et al. (2017) identified that the amino acid region $167-333$ of the replicase is responsible for this interaction. DNA viruses such as gemniviruses do not encode their own DNA-polymerase; instead, they utilize the host nuclear DNA replication machinery and reprogram the expression of many plant genes. To ensure a successful long-term infection, these viruses restrain their destructive effect on host cells, delaying or preventing cell death by interfering with the plant cell death pathway 
Table 1. Successful thermotherapy applied to various plant viruses $*^{*}-$ thermotherapy was also combined with cryotherapy or chemotherapy; $* *$ - temperature gradient with the posterior isolation and culture of apical meristems; *** - symptoms that were not mentioned in the selected reference, were derived from an online database by Brunt et al. 1996). Several examples, which are alphabetically ordered are shown.

\begin{tabular}{ll}
\hline Virus & Plant \\
\hline *Apple chlorotic leaf spot virus & $\begin{array}{l}\text { Malus domestica (4 } \\
\text { different cultivars) } \\
\text { (ACLSV) }\end{array}$ \\
*Apple necrosis mosaic virus (ApNMV) & \\
*Apple stem pitting virus (ASPV) & \\
*Apple stem grooving virus (ASGV) & \\
Apple chlorotic leaf spot virus (ACLSV) & Pyrus pyrifolia cv. \\
& Fengshui \\
Apple stem grooving virus (ASGV) & \\
Apple stem pitting virus (ASPV) & \\
**Apple chlorotic leaf spot virus & $\begin{array}{l}\text { Malus domestica } \\
\text { (ACLSV) }\end{array}$ \\
**Apple mosaic virus (ApMV) & $\begin{array}{l}\text { Pyrus communis } \\
\text { (2 cultivars) }\end{array}$
\end{tabular}

Apple chlorotic leaf spot virus (ACLSV) Pyrus pyrifolia Apple stem grooving virus (ASGV)

ACLSV: plum pseudo pox

(Tan et al. 2010)

ASGV: tatter leaf symptoms in citrus

ASPV: pear vein yellowing, leaf necrotic spot and fruit stone pitting growth retardation and loss of productivity

(Lizárraga et al. 2017)

Generally asymptomatic in most cultivars.

(Hu et al. 2012)

ACLSV can cause leaf malformation and chlorotic rings or line patterns in some pear cultivars,

ASGV: pear black necrotic leaf spot

*Apple stem grooving virus (ASGV)

In vitro-cultured apple shoots latent virus causing graft incompatibility,

Malus domestica reduced growth vigor and decreased fruit yield

Grapevine leafroll-associated virus $\operatorname{Pr} \quad$ Vitis vinifera GRSPaV-rugose wood syndrome of grapevine

(Zhao et al. 2018) (GLRaV-Pr)

Grapevine rupestris stem pitting associated virus (GRSPaV)

* Grapevine leafroll-associated virus 3 Vitis champini (GLRaV-3)

Lily symptomless virus (LSV)

Lilium $\times$ elegans

grapevine leafroll disease: apparent downward (Hu et al. 2020) curling and rolling of leaves. Virus can minimize shoot vigor and fruit yield and quality

Onion yellow dwarf virus (OYDV)

Plum pox virus (PPV)

Allium sativum

LSV decreases plant vigor and production

(Nesi et al. 2009) despite an apparent symptomless behavior

(Maliogka et al. 2009)

Prunus necrotic ringspot virus (PNRSV)

Potato leaf roll virus (PLRV)

Prunus persica var. poor fruit quality, reduction of productivity and (Manganaris et al. nectarina shortening of tree life 2003)

Potato virus $Y(\mathrm{PVY})$

Solanum tuberosum upward curling of leaves and vein swelling on (Abbas et al. 2016) young plants***

Solanum tuberosum mild to severe leaf mottling or streak or 'leaf- (AlMaarri et al. 2012)

*Raspberry bushy dwarf virus (RBDV) Rubus idaeus drop streak' with vein necrosis*** lower fruit mass and drupelet number per fruit, (Mathew et al. 2021) crumbly fruit, leaf yellowing and reduced cane growth

Raspberry bushy dwarf virus (RBDV) Rubus idaeus small or crumbly berries, yellow ring spots on (Wang et al. 2008) leaves that soon disappear***

Tomato spotted wilt tospovirus (TSWV) Nicotiana benthamiana firstly, chlorotic spots on apical leaves, rapidly (Roggero and Pennazio turning to bronze and dark-brown (necrosis) in 1997) tomato and pepper (Vaira et al. 1995) 
Table 2. Function of HSP70 as host factors during viral infections in plants. Studies targeting both upregulation (overexpression) or down regulation (loss of function mutants or silencing) of a protein have been used to confirm the function of HSP70 as a host factor. If HSP mutant plants have not been studied, N.A. (not applied) is indicated. Symptoms were derived from an online database by Brunt $e t$ al. 1996, Chl - chloroplastic, Mit - mitochondrial.

\begin{tabular}{|c|c|c|c|c|c|c|}
\hline Virus & Symptoms & Factor & $\begin{array}{l}\text { Up- }(\uparrow) \text { or } \\
\text { down- }(\downarrow) \\
\text { regulation }\end{array}$ & Nucleic aci & d Plant & Function \\
\hline $\begin{array}{l}\text { Red clover } \\
\text { necrotic } \\
\text { mosaic virus } \\
\text { (Mine et al. } \\
\text { 2012) }\end{array}$ & $\begin{array}{l}\text { necrotic local } \\
\text { lesions, mosaics, leaf } \\
\text { deformation }\end{array}$ & $\begin{array}{l}\text { HSP70 } \\
\text { HSP90 }\end{array}$ & $\downarrow$ & $(+)$ ssRNA & Nicotiana benthamiana & $\begin{array}{l}\text { HSP } 70 \text { and HSP } 90 \text { promote the } \\
\text { assembly of the VRC through } \\
\text { interactions with viral p } 27\end{array}$ \\
\hline $\begin{array}{l}\text { Tomato } \\
\text { bushy stunt } \\
\text { tombusvirus } \\
\text { (Pogany and } \\
\text { Nagy 2015) }\end{array}$ & $\begin{array}{l}\text { stunting, mottling, } \\
\text { deformed fruit, }\end{array}$ & HSP70 & N.A. & $(+)$ ssRNA & recombinant $R d R p$ & $\begin{array}{l}\text { HSP70 is host factor required } \\
\text { for the activation on N-terminal } \\
\text { truncated recombinant TBSV } \\
\text { RdRp. interaction with viral p33 } \\
\text { in VRC }\end{array}$ \\
\hline $\begin{array}{l}\text { Chinese wheat } \\
\text { mosaic virus } \\
\text { (Yang et al. } \\
\text { 2017) }\end{array}$ & $\begin{array}{l}\text { tchlorotic and necrotic } \\
\text { spots or netting }\end{array}$ & $\begin{array}{l}\text { NbHSP70 } \\
\text { TaHSP70 }\end{array}$ & $\uparrow$ & $(+)$ ssRNA & $\begin{array}{l}\text { Nicotiana benthamina } \\
\text { (silenced HSP70) } \\
\text { Triticum aestivum } \\
\text { (transiently } \\
\text { overexpressed HSP70 }\end{array}$ & $\begin{array}{l}\text { interaction with the region aa } \\
167-333 \text { of replicase. Both } \\
\text { HSP } 70 \text { are very probably } \\
\text { recruited into VRC to promote } \\
\text { furoviral replication. }\end{array}$ \\
\hline $\begin{array}{l}\text { Rice stripe } \\
\text { virus (Jiang et } \\
\text { al. 2014) }\end{array}$ & $\begin{array}{l}\text { systemic necrotic or } \\
t \text { chlorotic spots and } \\
\text { streaking }\end{array}$ & HSP70 & $\downarrow$ & $(-)$ ssRNA & $\begin{array}{l}\text { Oryza sativa } \\
\text { Nicotiana benthamiana } \\
\text { (silenced HSP70) }\end{array}$ & $\begin{array}{l}\text { HSP70 plays a role in viral } \\
\text { replication and probably in } \\
\text { interaction with RdRp }\end{array}$ \\
\hline $\begin{array}{l}\text { Turnip } \\
\text { mosaic virus } \\
\text { (Dufresne et } \\
\text { al. 2008) }\end{array}$ & $\begin{array}{l}\text { chlorotic local lesions, } \\
\text { mosaic, mottling, } \\
\text { puckering or rugosity }\end{array}$ & HSC70-3 & N.A. & $(+)$ ssRNA & Arabidopsis thaliana & $\begin{array}{l}\text { HSC70-3 is potentially integral } \\
\text { compartment of the replicase } \\
\text { complex and could has important } \\
\text { roles to play in the regulation of } \\
\text { RdRp functions. }\end{array}$ \\
\hline $\begin{array}{l}\text { Turnip } \\
\text { mosaic virus } \\
\text { (Jungkunz et } \\
\text { al. 2011) }\end{array}$ & & HSP70 & $\downarrow$ & $(+)$ ssRNA & $\begin{array}{l}\text { Arabidopsis thaliana } \\
\text { (AtHSP70-15 deficient) }\end{array}$ & $\begin{array}{l}\text { key factor in proper folding of } \\
\text { cytosolic proteins }\end{array}$ \\
\hline $\begin{array}{l}\text { Beet yellows } \\
\text { virus } \\
\text { (Peremyslov } \\
\text { et al. } 1999, \\
\text { Alzhanova } \\
\text { et al. 2001, } \\
\text { Prokhnevsky } \\
\text { et al. 2002) }\end{array}$ & $\begin{array}{l}\text { vein clearing, then } \\
\text { leaves become thick, } \\
\text { brittle, yellow with } \\
\text { necrotic spots }\end{array}$ & $\begin{array}{l}\text { HSP70h } \\
\text { (viral } \\
\text { homolog) }\end{array}$ & N.A. & $(+)$ ssRNA & $\begin{array}{l}\text { the mutant and wild type } \\
\text { full length cDNA viral } \\
\text { clones transcribed into } \\
\text { tobacco protoplasts }\end{array}$ & $\begin{array}{l}\text { HSP70 functions in intercellular } \\
\text { translocation, viral tail (special } \\
\text { device to cell-to cell movement) } \\
\text { assembly and transport and } \\
\text { severs as molecular link between } \\
\text { local and systemic spread of a } \\
\text { plant virus by docking a long- } \\
\text { distance transport protein (viral } \\
\text { p20) to virions. }\end{array}$ \\
\hline $\begin{array}{l}\text { Tomato bushy } \\
\text { stunt virus } \\
\text { (Wang et al. } \\
\text { 2009a) }\end{array}$ & $\begin{array}{l}\text { stunting, mottling, } \\
\text { deformed fruit }\end{array}$ & HSP70 & $\downarrow$ & $(+)$ ssRNA & Nicotiana benthamiana & $\begin{array}{l}\text { part of virus replicase complex. } \\
\text { HSP70 affects the subcellular } \\
\text { localization and membrane } \\
\text { insertion of the viral replication } \\
\text { proteins as well as assembly of } \\
\text { the viral replicase }\end{array}$ \\
\hline $\begin{array}{l}\text { Potato virus } \\
A, X \text {, and } Y \\
\text { (Hafren et al. } \\
\text { 2010) }\end{array}$ & $\begin{array}{l}\text { PVA: mild mosaic, leaf } \\
\text { surface rough with wavy } \\
\text { margins, or symptomless } \\
\text { PVX: symptoms } \\
\text { vary, some strains } \\
\text { symptomless, others } \\
\text { induce necrotic streaks } \\
\text { PVY: mild to severe leaf } \\
\text { mottling or streak or } \\
\text { 'leaf-drop streak' with } \\
\text { vein necrosis }\end{array}$ & $\begin{array}{l}\text { HSP70 } \\
\text { S }\end{array}$ & $\downarrow$ & $(+)$ ssRNA & $\begin{array}{l}\text { Nicotiana benthamiana } \\
\text { (downregulated HSP70) }\end{array}$ & $\begin{array}{l}\text { HSP70 together with its } \\
\text { cochaperone CPIP regulates the } \\
\text { function of a potyviral CP during } \\
\text { replication-associated translation. } \\
\text { HSP70 as a crucial component } \\
\text { of a distinct translational activity } \\
\text { that is associated with potyvirus } \\
\text { replication }\end{array}$ \\
\hline
\end{tabular}




\begin{tabular}{|c|c|c|c|c|c|c|}
\hline Virus & Symptoms & Factor & $\begin{array}{l}\text { Up- }(\uparrow) \text { or } \\
\text { down- }(\downarrow) \\
\text { regulation }\end{array}$ & $\begin{array}{l}\text { Nucleic } \\
\text { acid }\end{array}$ & Plant & Function \\
\hline $\begin{array}{l}\text { Tomato yellow } \\
\text { leaf curl virus } \\
\text { (Gorovits and } \\
\text { Czosnek 2017) }\end{array}$ & $\begin{array}{l}\text { plants stunted with } \\
\text { small chlorotic } \\
\text { puckered leaves; fruit } \\
\text { yield much decreased }\end{array}$ & $\begin{array}{l}\text { HSP70, not } \\
\text { HSP90 }\end{array}$ & $\downarrow$ & DNA & $\begin{array}{l}\text { Solanum } \\
\text { lycopersicum }\end{array}$ & $\begin{array}{l}\text { HSP70 participates in the } \\
\text { translocation of CP from the } \\
\text { cytoplasm into the nucleus }\end{array}$ \\
\hline $\begin{array}{l}\text { Tomato yellow } \\
\text { leaf curl virus } \\
\text { (Moshe et al. } \\
\text { 2016) }\end{array}$ & $\begin{array}{l}\text { plants stunted with } \\
\text { small chlorotic } \\
\text { puckered leaves; fruit } \\
\text { yield much decreased }\end{array}$ & HSP90 & $\downarrow$ & DNA & $\begin{array}{l}\text { Solanum } \\
\text { lycopersicum }\end{array}$ & $\begin{array}{l}\text { the suppression effect on cell death } \\
\text { is induced by the inhibition effect } \\
\text { of HSP } 90 \text { and its co-chaperone } \\
\text { SGT1. }\end{array}$ \\
\hline $\begin{array}{l}\text { Tomato yellow } \\
\text { leaf curl virus } \\
\text { (Anfoka et al. } \\
\text { 2016) }\end{array}$ & $\begin{array}{l}\text { plants stunted with } \\
\text { small chlorotic } \\
\text { puckered leaves; fruit } \\
\text { yield much decreased }\end{array}$ & $\begin{array}{l}\text { HSP90, } \\
\text { HSP17 }\end{array}$ & $\downarrow$ & DNA & $\begin{array}{l}\text { Solanum } \\
\text { lycopersicum } \\
\text { (with } \\
\text { downregulated } \\
\text { HSF and thus } \\
\text { HSP90) }\end{array}$ & $\begin{array}{l}\text { combined heat and viral stresses } \\
\text { induce the aggregation of HSP } 90 \\
\text { and HSP70. The maintenance } \\
\text { of cellular chaperones in the } \\
\text { aggregated state prevents the } \\
\text { circulation of free soluble forms } \\
\text { causing an additional decrease in } \\
\text { stress response efficiency. }\end{array}$ \\
\hline $\begin{array}{l}\text { Abutilon } \\
\text { mosaic virus } \\
\text { (Krenz et al. } \\
\text { 2010) }\end{array}$ & Yellow mosaic & cpHSC70-1 & $\downarrow$ & ssDNA & $\begin{array}{l}\text { Nicotiana } \\
\text { benthamiana } \\
\text { silenced } \\
\text { cpHSC70 }\end{array}$ & $\begin{array}{l}\text { functional relevance of viral } \\
\text { movement protein-chaperone } \\
\text { interaction for viral transport and } \\
\text { symptom induction }\end{array}$ \\
\hline $\begin{array}{l}\text { Pepino } \\
\text { mosaic virus } \\
\text { (Mathioudakis } \\
\text { et al. 2012) }\end{array}$ & $\begin{array}{l}\text { mosaic, dark green } \\
\text { enations on the abaxial } \\
\text { surfaces }\end{array}$ & HSC70 & N.A. & $(+)$ ssRNA & $\begin{array}{l}\text { Solanum } \\
\text { lycopersicum }\end{array}$ & $\begin{array}{l}\text { interaction with PepMV CP during } \\
\text { infection }\end{array}$ \\
\hline $\begin{array}{l}\text { Potato virus } Y \\
\text { (Hofius et al. } \\
\text { 2007) }\end{array}$ & $\begin{array}{l}\text { mild to severe leaf } \\
\text { mottling or streak or } \\
\text { 'leaf-drop streak' with } \\
\text { vein necrosis }\end{array}$ & $\begin{array}{l}\text { Dna-J like } \\
\text { proteins, } \\
\text { designated } \mathrm{Nt} \\
\text { CPIPs }\end{array}$ & $\uparrow$ & $(+)$ ssRNA & $\begin{array}{l}\text { Nicotiana } \\
\text { tabacum }\end{array}$ & $\begin{array}{l}\text { in vivo confirmation for the } \\
\text { essential role of plant chaperones } \\
\text { in virus movement. }\end{array}$ \\
\hline $\begin{array}{l}\text { Tobacco } \\
\text { mosaic virus } \\
\text { (Chen et al. } \\
\text { 2008) }\end{array}$ & $\begin{array}{l}\text { leaf mosaic, severe } \\
\text { crop losses }\end{array}$ & HSP70 & $\downarrow, \uparrow$ & $(+)$ ssRNA & $\begin{array}{l}\text { Nicotiana } \\
\text { benthamiana }\end{array}$ & $\begin{array}{l}\text { enhancement of } N \text {. benthamiana } \\
\text { viral infection by diverse viruses }\end{array}$ \\
\hline $\begin{array}{l}\text { Potato virus } \\
X(\text { Chen et al. } \\
2008)\end{array}$ & $\begin{array}{l}\text { symptoms vary, some } \\
\text { strains symptomless, } \\
\text { others induce necrotic } \\
\text { streaks }\end{array}$ & HSP70 & $\downarrow, \uparrow$ & $(+)$ ssRNA & $\begin{array}{l}\text { Nicotiana } \\
\text { benthamiana }\end{array}$ & $\begin{array}{l}\text { enhancement of } N \text {. benthamiana } \\
\text { viral infection by diverse viruses }\end{array}$ \\
\hline $\begin{array}{l}\text { Watermelon } \\
\text { mosaic virus } \\
\text { (Chen et al. } \\
\text { 2008) }\end{array}$ & $\begin{array}{l}\text { mosaic, mottling, } \\
\text { leaves and fruit } \\
\text { malformed }\end{array}$ & HSP70 & $\downarrow, \uparrow$ & $(+)$ ssRNA & $\begin{array}{l}\text { Nicotiana } \\
\text { benthamiana }\end{array}$ & $\begin{array}{l}\text { enhancement of } N \text {. benthamiana } \\
\text { viral infection by diverse viruses }\end{array}$ \\
\hline $\begin{array}{l}\text { Cucumber } \\
\text { mosaic virus } \\
\text { (Chen et al. } \\
\text { 2008) }\end{array}$ & $\begin{array}{l}\text { mosaics and stunting, } \\
\text { reduced fruit yield }\end{array}$ & HSP70 & $\downarrow, \uparrow$ & $(+)$ ssRNA & $\begin{array}{l}\text { Nicotiana } \\
\text { benthamiana }\end{array}$ & $\begin{array}{l}\text { enhancement of } N \text {. benthamiana } \\
\text { viral infection by diverse viruses }\end{array}$ \\
\hline $\begin{array}{l}\text { Tobacco } \\
\text { mosaic virus } \\
\text { (Jockusch et al. } \\
\text { 2001) }\end{array}$ & $\begin{array}{l}\text { leaf mosaic, severe } \\
\text { crop losses }\end{array}$ & $\begin{array}{l}\text { HSP18, } \\
\text { HSP70 }\end{array}$ & N.A. & $(+)$ ssRNA & $\begin{array}{l}\text { Nicotiana } \\
\text { tabacum } \\
\text { temperature } \\
\text { sensitive CP } \\
\text { mutants }\end{array}$ & $\begin{array}{l}\text { the induction of HSPs paralleled } \\
\text { the amount of insoluble CP in leaf } \\
\text { extracts. }\end{array}$ \\
\hline $\begin{array}{l}\text { Potato virus } Y \\
\text { (Makarova et } \\
\text { al. 2018) }\end{array}$ & $\begin{array}{l}\text { mild to severe leaf } \\
\text { mottling or streak or } \\
\text { 'leaf-drop streak' with } \\
\text { vein necrosis }\end{array}$ & \multicolumn{2}{|c|}{ HSP70 HSP90N.A. } & $(+)$ ssRNA & $\begin{array}{l}\text { Solanum } \\
\text { tuberosum } \\
\text { thermosensitive } \\
\text { and } \\
\text { thermoresistant } \\
\text { cultivar }\end{array}$ & $\begin{array}{l}\text { response to heat stress and PVY in } \\
\text { cultivar-specific manner. }\end{array}$ \\
\hline
\end{tabular}




\begin{tabular}{|c|c|c|c|c|c|}
\hline Symptoms & Factor & $\begin{array}{l}\text { Up- }(\uparrow) \text { or } \\
\text { down- }(\downarrow) \\
\text { regulation }\end{array}$ & $\begin{array}{l}\text { Nucleic } \\
\text { acid }\end{array}$ & Plant & Function \\
\hline $\begin{array}{l}\text { Potato virus necrotic middle veins } \\
\text { Y, strain NTN, and chlorotic, crincled } \\
\text { (Hyskova et al. leaves with mosaic } \\
\text { 2021) }\end{array}$ & $\begin{array}{l}\text { cytosolic } \\
\text { HSP70, Chl. } \\
\text { HSP70, Mit. } \\
\text { HSP70, } \\
\text { HSP90-1 }\end{array}$ & N.A. & $(+)$ ssRNA & $\begin{array}{l}\text { Nicotiana } \\
\text { tabacum }\end{array}$ & $\begin{array}{l}\text { the order of HS application } \\
\text { and inoculation affect the virus } \\
\text { propagation. In the beginning HSPs } \\
\text { help the virus, but at a later stage } \\
\text { specific isoforms could be also part } \\
\text { of the plant's defense. }\end{array}$ \\
\hline
\end{tabular}

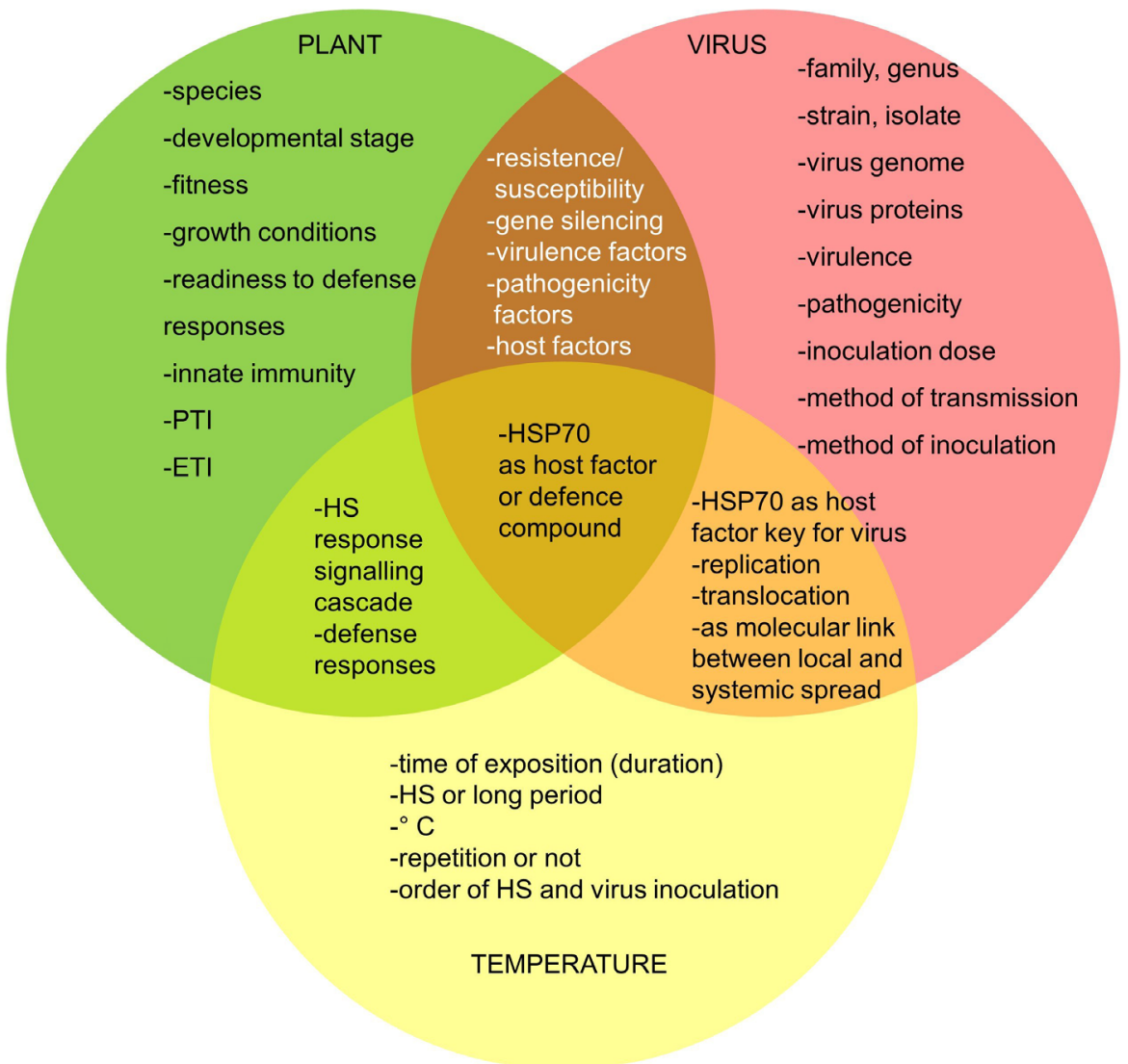

Fig. 2. Factors and conditions that determine whether HSP70 will act as host factor accelerating virus replication and spread or as a defense compound.

(Anfoka et al. 2016, Moshe et al. 2016). Tomato yellow leaf curl viruses suppress cell death induced by the inhibition of HSP90 (Moshe et al. 2016).

Viral coat proteins (CP) act as multifunctional proteins involved in almost every stage of the viral infection cycle. Their versatility is achieved via specific CP interactions with viral and host components in the infected cell (Ivanov and Makinen 2012). Hafren et al. (2010) found that the function of a potyviral CP (which can interfere with viral gene expression) is regulated by HSP70 together with its co-chaperone capsid protein interacting protein (CPIP). Other studies also suggest that HSP70 affects viral CP local movement from cell to cell or long-distance transport through the vascular system (Table 2). Some viruses (Closteroviruses) even form viral HSP70 homologs, which enable their translocation (Karasev 2000, Alzhanova et al. 2001). Thus, Closteroviruses, for example, need a specialized movement device with HSP70h most likely because they are exceptionally long (Alzhanova et al. 2001). Similarly, a subsequent study highlighted a new function of the HSP70 viral homolog as a molecular link between the local and systemic spread of Beet yellows virus by docking the long-distance transport factor p20 to virions (Prokhnevsky et al. 2002).

Cytoplasmic HSP70 enhances Nicotiana benthamiana infection with Tobacco mosaic virus, Potato virus $X$, and Watermelon mosaic virus (Chen et al. 2008). Heat stress inhibits the tobacco and potato hypersensitive response to Tobacco mosaic virus and Potato virus X (Kiraly et al. 2008, Wang et al. 2009b). For example, in plants, HSP70 silencing by RNAi technology or chemical inhibition of HSP70 expression impairs a number of positive sense, 
single-stranded RNA viruses (Wang 2015). Mutant HSP70-deficient plants exhibit reduced virus content and delayed infection onset (Hafren et al. 2010, Jiang et al. 2014, Gorovits and Czosnek 2017, Huang et al. 2017). Furthermore, HSP-deficient Arabidopsis plants are more tolerant to Turnip mosaic virus (Jungkunz et al. 2011), and HSP70 overexpression has been correlated with the accumulation of furoviral genomic RNAs (Yang et al. 2017). Interestingly, the potato cultivar resistant to Potato virus $Y$ is also thermotolerant, with HSP70 increasing only at elevated temperature and not due to viral infection. Conversely, the Potato virus $Y$ and thermosensitive potato cultivar also shows increased HSP70 synthesis in response to viral infection (Makarova et al. 2018).

The order of HS application and inoculation affects the virus propagation. HSP70 cytosolic, chloroplastic, and mitochondrial isoforms and stress-induced Hsp90-1 were significantly increased due to HS immediately after inoculation and then declined. On the other hand, cytosolic and mitochondrial Hsp70 with lower molecular mass were enhanced simultaneously with viral propagation and increase of salicylic acid content.

Hatch-Slack cycle enzymes that serve as markers of Potato virus $Y$ infection do not respond to HS, so the activity of phosphoenolpyruvate carboxylase, NADP-malic enzyme, and pyruvate, phosphate dikinase corresponds to infection, regardless of previous HS treatment (Hýsková et al. unpublished results).

During human diseases as well, several HSPs70 are associated with viral particles, e.g., rabies virus, hepatitis $C$ virus, adenovirus, the human immunodeficiency virus type 1 , and Zika virus. In such infections, HSPs70 usually act as an infection factor promoting viral transcriptional activity and spread (Milani et al. 2016, Bolhassani and Agi 2019). HSP70 even serves as a biomarker and drugs targeting HSP70 (HSP70 inhibitors) are attractive candidates for therapeutics targeting various viruses, such as the Zika virus, which is intensively studied in connection with HSP70 inhibitors (Taguwa et al. 2019).

\section{Conclusions}

Many factors, conditions, and circumstances determine whether elevated temperature or HS inducing HSP70 promote or inhibit viral replication and propagation in plants (Fig. 2). In addition to predetermined factors (Fig. 2), such as plant species, innate immunity, or virus pathogenicity, the combination in time and space of plant predispositions, HSP70 content and viral infection affect the resulting function of HSP70 in the plant during a viral infection. Crosslinking individual signaling pathways (UPR, HSF, ROS, ROS scavengers and hypersensitive response, gene silencing) temporally and spatially determines the role of HSP70 in a virus-infected plant. Furthermore, the process known as acquired thermo-tolerance can interfere with plant defense responses.

\section{References}

Abbas, A., Arif, M., Ali, A.: Use of hot water-thermotherapy to free potato tubers of Potato leaf roll virus (PLRV). - Int. J. Life Sci. sci. Res. 2: 155-162, 2016.

Achachi, A., Ait Barka, E., Ibriz, M.: Recent advances in Citrus psorosis virus. - Virus Disease 25: 261-276, 2014.

Aguilar-Camacho, M., Mora-Herrera, M.E., López-Delgado, H.A.: Potato virus $X$ (PVX) elimination as short and long term effects of hydrogen peroxide and salicylic acid is differentially mediated by oxidative stress in synergism with thermotherapy. - Amer. J. Potato Res. 93: 360-367, 2016.

AlMaarri, K., Massa, R., AlBiski, F.: Evaluation of some therapies and meristem culture to eliminate Potato $Y$ potyvirus from infected potato plants. - Plant Biotechnol. 29: 237-243, 2012.

Alzhanova, D.V., Napuli, A.J., Creamer, R., Dolja, V.V.: Cell-tocell movement and assembly of a plant closterovirus: roles for the capsid proteins and Hsp70 homolog. - EMBO J. 20: 6997-7007, 2001.

Anaraki, Z.E., Tafreshi, S.A.H., Shariati, M.: Transient silencing of heat shock proteins showed remarkable roles for HSP70 during adaptation to stress in plants. - Environ. exp. Bot. 155: 142-157, 2018.

Anfoka, G., Moshe, A., Fridman, L., Amrani, L., Rotem, O., Kolot, M., Zeidan, M., Czosnek, H., Gorovits, R.: Tomato yellow leaf curl virus infection mitigates the heat stress response of plants grown at high temperatures. - Sci. Rep. 6: 19715, 2016.

Aparicio, F., Thomas, C.L., Lederer, C., Niu, Y., Wang, D., Maule, A.J.: Virus induction of heat shock protein 70 reflects a general response to protein accumulation in the plant cytosol. - Plant Physiol. 138: 529-536, 2005.

Asea, A.A.A., Calderwood, S.K., Kaur, P (ed.): Heat Shock Proteins and Plants - Springer, Switzerland, 2016.

Bolhassani, A., Agi, E.: Heat shock proteins in infection. - Clin. chim. Acta 498: 90-100, 2019.

Brunt, A.A., Crabtree, K., Dallwitz, M.J., Gibbs, A.J., Watson, L., Zurcher, E.J. (ed.): Descriptions and Lists from the VIDE Database, CAB International, Wallingford, UK, 1990, ISBN : 9780851986630

Carr, J.P., Murphy, A.M., Tungadi, T., Yoon, J.Y.: Plant defense signals: players and pawns in plant-virus-vector interactions. - Plant Sci. 279: 87-95, 2019.

Chen, Z., Zhou, T., Wu, X., Hong, Y., Fan, Z., Li, H.: Influence of cytoplasmic heat shock protein 70 on viral infection of Nicotiana benthamiana. - Mol. Plant Pathol. 9: 809-817, 2008.

Doubnerova, V., Ryslava, H.: Roles of Hsp70 in plant abiotic stress. - In: Gaur, R.K., Sharma, P. (ed.): Molecular Approaches in Plant Abiotic Stress, Pp. 44-66. CRC Press, Boca Raton - London - New York 2014.

Driedonks, N., Xu, J., Peters, J.L., Park, S., Rieu, I.: Multi-level interactions between heat shock factors, heat shock proteins, and the redox system regulate acclimation to heat. - Front Plant Sci. 6: 999, 2015.

Duck, N.B., Folk, W.R.: Hsp70 heat shock protein cognate is expressed and stored in developing tomato pollen. - Plant mol. Biol. 26: 1031-1039, 1994.

Dufresne, P.J., Thivierge, K., Cotton, S., Beauchemin, C., Ide, C., Ubalijoro, E., Laliberté, J.F., Fortin, M.G.: Heat shock 70 protein interaction with Turnip mosaic virus RNA-dependent RNA polymerase within virus-induced membrane vesicles. Virology 374: 217-227, 2008.

Frydman, J.: Folding of newly translated proteins in vivo: the role of molecular chaperones. - Annu. Rev. Biochem. 70: 603-647, 
2001

Gaffar, F.Y., Koch, A.: Catch me if you can! RNA silencingbased improvement of antiviral plant immunity. - Viruses 11: 673, 2019.

Ghazaei, C.: Role and mechanism of the Hsp70 molecular chaperone machines in bacterial pathogens. - J. Med. Microbiol. 66: 259-265, 2017.

Gorovits, R., Czosnek, H.: The involvement of heat shock proteins in the establishment of Tomato yellow leaf curl virus infection. - Front. Plant Sci. 8: 355, 2017.

Gouveia, B.C., Calil, I.P., Machado, J.P., Santos, A.A., Fontes, E.P.: Immune receptors and co-receptors in antiviral innate immunity in plants. - Front. Microbiol. 7: 2139, 2017.

Hafrén, A., Hofius, D., Ronnholm, G., Sonnewald, U., Makinen, K.: HSP70 and its cochaperone CPIP promote Potyvirus infection in Nicotiana benthamiana by regulating viral coat protein functions. - Plant Cell 22: 523-535, 2010.

Haq, S.u., Khan, A., Ali, M., Khattak, A.M., Gai, W.-X., Zhang, H.-X., Wei, A.-M., Gong, Z.-H.: Heat shock proteins: dynamic biomolecules to counter plant biotic and abiotic stresses. - Int. J. Mol. Sci. 20: 5321, 2019

Hartl, F.U., Bracher, A., Hayer-Hartl, M.: Molecular chaperones in protein folding and proteostasis. - Nature 475: 324-332, 2011.

Heinlein, M.: Plasmodesmata: channels for viruses on the move. - Methods mol. Biol. 1217: 25-52, 2015.

Hofius, D., Maier, A.T., Dietrich, C., Jungkunz, I., Bornke, F., Maiss, E., Sonnewald, U.: Capsid protein-mediated recruitment of host DnaJ-like proteins is required for Potato virus $Y$ infection in tobacco plants. - J. Virol. 81: 1187011880, 2007

Hu, G., Dong, Y., Zhang, Z., Fan, X., Ren, F.: Elimination of apple necrosis mosaic virus from potted apple plants by thermotherapy combined with shoot-tip grafting. - Sci. Hort. 252: 310-315, 2019.

Hu, G., Dong, Y., Zhang, Z., Fan, X., Ren, F.: Efficiency of chemotherapy combined with thermotherapy for eliminating grapevine leafroll-associated virus 3 (GLRaV-3). - Sci. Hort. 271: 109462, 2020.

Hu, G.J., Hong, N., Wang, L.P., Hu, H.J., Wang, G.P.: Efficacy of virus elimination from in vitro-cultured sand pear (Pyrus pyrifolia) by chemotherapy combined with thermotherapy. Crop Protect. 37: 20-25, 2012.

Huang, Y.W., Hu, C.C., Tsai, C.H., Lin, N.S., Hsu, Y.H.: Chloroplast Hsp70 isoform is required for age-dependent tissue preference of Bamboo mosaic virus in mature Nicotiana benthamiana leaves. - Mol. Plant Microbe Interact. 30: 631$645,2017$.

Hyskova, V., Belonoznikova, K., Doricova, V., Kavan, D., Gillarova, S., Henke, S., Synkova, H., Ryslava, H., Cerovska, $\mathrm{N}$. Effects of heat treatment on metabolism of tobacco plants infected with Potato virus Y. - Plant Biol. 2021 Epub ahead of print. PMID: 33417742

Ivanov, K.I., Eskelin, K., Lohmus, A., Makinen, K.: Molecular and cellular mechanisms underlying potyvirus infection. - J. gen. Virol. 95: 1415-1429, 2014.

Ivanov, K.I., Makinen, K.: Coat proteins, host factors and plant viral replication. - Curr. Opin. Virol. 2: 712-718, 2012.

Jiang, C., Xu, J., Zhang, H., Zhang, X., Shi, J., Li, M., Ming, F.: A cytosolic class I small heat shock protein, RcHSP17.8, of Rosa chinensis confers resistance to a variety of stresses to Escherichia coli, yeast and Arabidopsis thaliana. - Plant Cell Environ. 32: 1046-1059, 2009.

Jiang, S., Lu, Y., Li, K., Lin, L., Zheng, H., Yan, F., Chen, J.: Heat shock protein 70 is necessary for Rice stripe virus infection in plants. - Mol. Plant Pathol. 15: 907-917, 2014.
Jockusch, H., Wiegand, C., Mersch, B., Rajes, D.: Mutants of Tobacco mosaic virus with temperature-sensitive coat proteins induce heat shock response in tobacco leaves. - Mol. Plant Microbe Interact. 7: 914-917, 2001.

Jungkunz, I., Link, K., Vogel, F., Voll, L.M., Sonnewald, S., Sonnewald, U.: AtHsp70-15-deficient Arabidopsis plants are characterized by reduced growth, a constitutive cytosolic protein response and enhanced resistance to TuMV. - Plant J. 66: 983-995, 2011.

Karasev, A.V.: Genetic diversity and evolution of Closteroviruses. - Annu. Rev. Phytopathol. 38: 293-324, 2000.

Kim, M.Y., Oglesbee M.: Virus-heat shock protein interaction and a novel axis for innate antiviral immunity. - Cells 1: 646666, 2012

Király, L., Hafez, Y.M., Fodor, J., Király, Z.: Suppression of tobacco mosaic virus-induced hypersensitive-type necrotization in tobacco at high temperature is associated with downregulation of NADPH oxidase and superoxide and stimulation of dehydroascorbate reductase. - J. gen. Virol. 89: 799-808, 2008.

Krenz, B., Windeisen, V., Wege, C., Jeske, H., Kleinow, T.: A plastid-targeted heat shock cognate $70 \mathrm{kDa}$ protein interacts with the Abutilon mosaic virus movement protein. - Virology 401: 6-17, 2010.

Kwon, Y., Kabir, M.A., Wang, H.W., Karuppanapandian, T., Moon, J.-C., Ryu, K.H., Lee, G.P., Kim, W.: Elimination of pepper mild mottle virus from infected tobacco (Nicotiana benthamiana L.) plants by callus culture and the sieving technique. - In Vitro cell. dev. Biol. Plant 48: 595-599, 2012.

Lee, J.H., Schoffl, F.: An Hsp70 antisense gene affects the expression of HSP70/HSC70, the regulation of HSF, and the acquisition of thermotolerance in transgenic Arabidopsis thaliana. - Mol. gen. Genet. 252: 11-19, 1996.

Li, B., Gao, K., Ren, H., Tang, W.: Molecular mechanisms governing plant responses to high temperatures. - J. integr Plant Biol. 60: 757-779, 2018.

Liu, J., Pang, X., Cheng, Y., Yin, Y., Zhang, Q., Su, W., Hu, B., Guo, Q., Ha, S., Zhang, J., Wan, H.: The Hsp70 gene family in Solanum tuberosum: genome-wide identification, phylogeny, and expression patterns. - Sci Rep. 8: 16628, 2018.

Lizárraga, A., Ascasíbar, J., González, M.L.: Fast and effective thermotherapy treatment for in vitro virus eradication in apple and pear trees. - Amer. J. Plant Sci. 8: 2474-2482, 2017.

Lohmus, A., Hafrén, A., Makinen, K.: Coat protein regulation by CK2, CPIP, HSP70, and CHIP is required for Potato Virus $A$ replication and coat protein accumulation. - J. Virol. 91: e01316-16, 2017

Makarova, S., Makhotenko, A., Spechenkova, N., Love, A.J., Kalinina, N.O., Taliansky, M.: Interactive responses of potato (Solanum tuberosum L.) plants to heat stress and infection with Potato virus Y. - Front. Microbiol. 9: 2582, 2018

Maliogka, V.I., Skiada, F.G., Eleftheriou, E.P., Katis, N.I.: Elimination of a new ampelovirus (GLRaV-Pr) and Grapevine rupestris stem pitting associated virus (GRSPaV) from two Vitis vinifera cultivars combining in vitro thermotherapy with shoot tip culture. - Sci. Hort. 123: 280-282, 2009.

Manganaris, G.A., Economou, A.S., Boubourakas, I.N., Katis, N.I.: Elimination of PPV and PNRSV through thermotherapy and meristem-tip culture in nectarine. - Plant Cell Rep. 22: 195-200, 2003.

Mathew, L., Tiffin, H., Erridge, Z., McLachlan, A., Hunter, D., Pathirana, R.: Efficiency of eradication of Raspberry bushy dwarf virus from infected raspberry (Rubus idaeus) by in vitro chemotherapy, thermotherapy and cryotherapy and their combinations. - Plant Cell Tissue Organ Cult. 144: 133-141, 2021. 
Mathioudakis, M.M., Veiga, R., Ghita, M., Tsikou, D., Medina, V., Canto, T., Makris, A.M., Livieratos, I.C.: Pepino mosaic virus capsid protein interacts with a tomato heat shock protein cognate 70. - Virus Res. 163: 28-39, 2012.

Mayer, M.P., Bukau, B.: Hsp70 chaperones: cellular functions and molecular mechanism. - Cell Mol. Life Sci. 62: 670-684, 2005.

Milani, A., Basirnejad, M., Shahbazi, S., Bolhassani, A.: HSP roles as biomarkers and antigens in bacterial and viral infections. - J. Med. Microbiol. Infect. Dis. 4: 1-7, 2016.

Mine, A., Hyodo, K., Tajima, Y., Kusumanegara, K., Taniguchi, T., Kaido, M., Mise, K., Taniguchi, H., Okuno, T.: Differential roles of Hsp70 and Hsp90 in the assembly of the replicase complex of a positive-strand RNA plant virus. - J. Virol. 86: 12091-12104, 2012.

Mittler, R., Finka, A., Goloubinoff, P.: How do plants feel the heat? - Trends Biochem. Sci. 37: 118-125, 2012.

Morimoto, R.I., Jurivich, D.A., Kroeger, P.E., Mathur, S.K., Murphy, S.P., Nakai, A., Sarge, K., Abravaya, K., Sistonen, L.T.: Regulation of heat shock gene transcription by a family of heat shock transcription factors. - In: Morimoto, R.I., Tissieres, A., Georgopoulos, C. (eds.): The Biology of Heat Shock Proteins and Molecular Chaperones. Cold Spring Harbor Laboratory Press, Cold Spring Harbor, NY, Pp. 417455, 1994, ISBN: 0879694270.

Moshe, A., Gorovits, R., Liu, Y., Czosnek, H.: Tomato plant cell death induced by inhibition of HSP90 is alleviated by Tomato yellow leaf curl virus infection. - Mol. Plant Pathol. 17: 247260, 2016.

Nagy, P.D., Wang, R.Y., Pogany, J., Hafren, A., Makinen, K.: Emerging picture of host chaperone and cyclophilin roles in RNA virus replication. - Virology 411: 374-382, 2011.

Nesi, B., Trinchello, D., Lazzereschi, S., Grassotti, A., Ruffoni, B.: Production of lily symptomless virus-free plants by shoot meristem tip culture and in vitro thermotherapy. - Hort. Sci. 44: 217-219, 2009

Park, C.J., Seo, Y.S.: Heat shock proteins: a review of the molecular chaperones for plant immunity. - Plant Pathol. J. 31: 323-333, 2015.

Peremyslov, V.V., Hagiwara, Y., Dolja, V.V.: HSP70 homolog functions in cell-to-cell movement of a plant virus. - Proc. nat. Acad. Sci. USA 96: 14771-14776, 1999.

Pogany, J., Nagy, P.D.: Activation of Tomato bushy stunt virus RNA-dependent RNA polymerase by cellular heat shock protein 70 is enhanced by phospholipids in vitro. - J. Virol. 89: 5714-5723, 2015

Prerostova, S., Dobrev, P.I., Kramna, B., Gaudinova, A., Knirsch, V., Spichal, L., Zatloukal, M., Vankova, R.: Heat acclimation and inhibition of cytokinin degradation positively affect heat stress tolerance of Arabidopsis. - Front. Plant Sci. 11: 87, 2020.

Prokhnevsky, A.I., Peremyslov, V.V., Napuli, A.J., Dolja, V.V.: Interaction between long-distance transport factor and Hsp70related movement protein of Beet yellows virus. - J. Virol. 76: 11003-11011, 2002.

Robert, U., Žel, J., Ravnikar, M.: Thermotherapy in virus elimination from garlic: influences on shoot multiplication from meristems and bulb formation in vitro. - Sci. Hort. 73: 193-202, 1998.

Roggero, P., Pennazio, S.: Thermal inactivation of tomato spotted wilt tospovirus in vivo. - Physiol. mol. Plant Pathol. 51: 35-40, 1997.

Samakovli, D., Ticha, T., Vavrdova, T., Ovecka, M., Luptovciak, I., Zapletalova, V., Kucharova, A., Krenek, P., Krasylenko, Y., Margaritopoulou, T., Roka, L., Milioni, D., Komis, G., Hatzopoulos, P., Samaj, J.: YODA-HSP90 module regulates phosphorylation-dependent inactivation of SPEECHLESS to control stomatal development under acute heat stress in Arabidopsis. - Mol. Plant 13: 612-633, 2020.

Song, Z., Pan, F., Lou, X., Wang, D., Yang, C., Zhang, B., Zhang, H.: Genome-wide identification and characterization of Hsp70 gene family in Nicotiana tabacum. - Mol. Biol. Rep. 46: 1941-1954, 2019.

Su, P.H., Li, H.M.: Arabidopsis stromal 70-kD heat shock proteins are essential for plant development and important for thermotolerance of germinating seeds. - Plant Physiol. 146: 1231-1241, 2008.

Sun, L., Liu, Y., Kong, X., Zhang, D., Pan, J., Zhou, Y., Wang, L., Li, D., Yang, X.: ZmHSP16.9, a cytosolic class I small heat shock protein in maize (Zea mays), confers heat tolerance in transgenic tobacco. - Plant Cell Rep. 31: 1473-1484, 2012.

Szittya, G., Silhavy, D., Molnar, A., Havelda, Z., Lovas, A., Lakatos, L., Banfalvi, Z., Burgyan, J.: Low temperature inhibits RNA silencing-mediated defence by the control of siRNA generation. - EMBO J. 22: 633-640, 2003.

Taguwa, S., Yeh, M.T., Rainbolt, T.K., Nayak, A., Shao, H., Gestwicki, J.E., Andino, R., Frydman, J.: Zika virus dependence on host Hsp70 provides a protective strategy against infection and disease. - Cell Rep. 26: 906-920, 2019.

Tan, R., Wang, L., Hong, N., Wang, G.: Enhanced efficiency of virus eradication following thermotherapy of shoot-tip cultures of pear. - Plant Cell Tissue Organ Cult. 101: 229-235, 2010.

Usman, M.G., Rafii, M.Y., Martini, M.Y., Yusuff, O.A., Ismail, M.R., Miah, G.: Molecular analysis of Hsp70 mechanisms in plants and their function in response to stress. - Biotechnol. Genet. Eng. Rev. 33: 26-39, 2017.

Vaira, A.M., Semeria, L., Crespi, S., Lisa, V., Allavena, A., Accotto, G.P.: Resistance to tospoviruses in Nicotiana benthamiana transformed with the $\mathrm{N}$ gene of tomato spotted wilt virus: correlation between transgene expression and protection in primary transformants. - Mol. Plant Microbe Interact. 8: 66-73, 1995.

Verchot, J.: Cellular chaperones and folding enzymes are vital contributors to membrane bound replication and movement complexes during plant RNA virus infection. - Front. Plant Sci. 3: 275, 2012.

Wang, A.: Dissecting the molecular network of virus-plant interactions: the complex roles of host factors. - Annu. Rev. Phytopathol. 53: 45-66, 2015.

Wang, M.R., Cui, Z.H., Li, J.W., Hao, X.Y., Zhao, L., Wang, Q.C.: In vitro thermotherapy-based methods for plant virus eradication. - Plant Methods 14: 87, 2018.

Wang, Q., Cuellar, W.J., Rajamaki, M.L., Hirata, Y., Valkonen, J.P.: Combined thermotherapy and cryotherapy for efficient virus eradication: relation of virus distribution, subcellular changes, cell survival and viral RNA degradation in shoot tips. - Mol. Plant Pathol. 9: 237-250, 2008.

Wang, R.Y., Stork, J., Pogany, J., Nagy, P.D.: A temperature sensitive mutant of heat shock protein 70 reveals an essential role during the early steps of tombusvirus replication. Virology 394: 28-38, 2009a.

Wang, Y., Bao, Z., Zhu, Y., Hua, J.: Analysis of temperature modulation of plant defense against biotrophic microbes. Mol. Plant Microbe Interact. 22: 498-506, 2009b.

Wang, W., Vinocur, B., Shoseyov, O., Altman, A.: Role of plant heat-shock proteins and molecular chaperones in the abiotic stress response. - Trends Plant Sci. 9: 244-252, 2004.

Yang, J., Zhang, F., Cai, N.J., Wu, N., Chen, X., Li, J., Meng, X.F., Zhu, T.Q., Chen, J.P., Zhang, H.M.: A furoviral replicase recruits host HSP70 to membranes for viral RNA replication. - Sci. Rep. 7: 45590, 2017. 
Zhao, L., Wang, M.R., Cui, Z.H., Chen, L., Volk, G.M., Wang, Q.C.: Combining thermotherapy with cryotherapy for efficient eradication of apple stem grooving virus from infected invitro-cultured apple shoots. - Plant Dis. 102: 1574-1580, 2018. 